\title{
PENDEKATAN MODEL KOOPERATIF TIPE STUDENT TEAMS ACHIEVEMENT DIVISION (STAD) UNTUK MENINGKATKAN MOTIVASI DAN PRESTASI PEMBELAJARAN KIMIA MAN 2 KOTA PADANG
}

\author{
Maywai Loza \\ Madrasah Aliyah Negeri 2 Padang \\ Email: maywailoza66@gmail.com
}

\begin{abstract}
Abstrak: Proses pembelajaran memerlukan strategi pembelajaran yang tepat dan efektif guna mencapai tujuan pembelajaran yang diharapkan. Kecocokan strategi pembelajaran dengan kondisi siswa sangat berdampak terhadap hasil proses pembelajaran siswa. Pendekatan model kooperatif tipe STAD dipandang cocok untuk memotivasi dan meninggkatkan partisipasi siswa dalam proses pembelajaran kimia pada siswa kelas X IS 2 MAN 2 Kota Padang. Sehubungan dengan itu telah dilakukan penelitian tidakan kelas yang bertujuan untuk mengetahui penerapan model kooperatif tipe STAD diserta LKS dan peta konsep dalam mata pelajaran kimia lintas minat pada siswa kelas $\mathrm{X}$ IS 2 MAN 2 Kota Padang. Penelitian tindakan kelas dirancang dengan menggunakan pendekatan model kooperatif tipe STAD diserta LKS dan peta konsep pada materi ikatan kimia. Kelas sampel penelitian adalah siswa kelas X IS 2 MAN 2 Kota Padang yang terdaftar pada semester ganjil tahun pembelajaran 2017/2018 dengan jumlah siswa 39 orang. Penelitian terdiri dari dua siklus dan setiap siklus terdiri dari empat tahap (perencanaan, pelaksanaan, evalusi dan refleksi), pada siklus 1 adalah STAD diserta LKS dan pada siklus 2 adalah STAD diserta LKS dan peta konsep. Hasil penelitian menunjukan bahwa pendekatan model kooperatif tipe STAD disertai dengan LKS dan peta konsep dapat meningkat hasil pembelajaran kognitif, aktifitas positif dan menurunkan aktifitas negatif dalam pembelajaran kimia lintas minat pada siswa kelas X IS 2 MAN 2 Kota Padang.
\end{abstract}

Kata kunci: STAD, kopetensi kognitif, aktifitas siswa, pembelajaran kimia

\section{PENDAHULUAN}

Guru professional bertugas mentransfer materi dan mengajarkan serta berupaya membangun proses pencerdasan siswa. Guru harus berani bertindak dan mengemukakan ide-ide yang inovatif untuk mampu mendorong tumbuhnya sikap kreatif siswa dan senantiasa kreatif untuk menampilkan pikiran-pikiran alternatif. Selain itu, guru juga dituntut secara dinamis mengembangkan diri melalui proses pembelajaran terbuka dan menyenangkan. Guru harus menggunakan strategi yang tepat agar siswa dapat belajar secara efektif dan efisien sesuai tujuan yang diharapkan.

Berbagai upaya telah dilakukan guru untuk meningkatkan partisipasi siswa dalam proses pembelajaran. Guru berupaya melakukan pemilihan model dan pendekatan pembelajaran untuk meningkatkan hasil belajar siswa. Salah satu metode pembelajaran yang diduga kuat dapat meningkatkan peran aktif siswa dalam kegiatan proses pembelajaran adalah Model pembelajaran kooperatif tipe student teams achievement division (STAD).

Model pembelajaran kooperatif tipe student teams achievement division (STAD) merupakan salah satu pembelajaran kooperatif yang diterapkan untuk menghadapi kemampuan siswa yang heterogen. Model STAD dipandang sebagai suatu metode yang paling sederhana dan langsung dari pendekatan 
pembelajaran kooperatif. Metode tersebut dikembangkan dalam bentuk belajar kooperatif. Pada model tersebut siswa diberi kesempatan untuk melakukan kolaborasi dan elaborasi dengan teman sebaya dalam bentuk diskusi kelompok untuk memecahkan suatu permasalahan (Arindawati, 2004)

Pembelajaran kooperatif yang menggunakan pendekatan STAD terdiri dari beberapa langkah. langkah-langkah dari STAD terdiri dari penyajian materi, kegiatan kelompok, tes individu, perhitungan skor setiap individu dan penghargaan kelompok. Guru bisa menyajikan materi baik secara klasikal atau pun melalui diskusi, dan tetap harus menyusun perencanaan pelaksanaan pembelajaran dan mempersiapkan lembar kerja peserta didik atau panduan belajar peserta didik, pembentukan kelompok belajar dan menjelaskan pada peserta didik tentang tugas dan perannya dalam kelompok, juga mengenai perencanaan waktu dan tempat duduk peserta didik. Supaya proses pembelajaran terlaksana dengan baik segala sesuatunya harus dipersiapkan dengan baik pula, agar peran aktif peserta didik dan demokrasi benar-benar terlaksana (Slavin, 2009).

Lembar Kerja Siswa (LKS) adalah sumber belajar penunjang yang digunakan untuk meningkatkan pemahaman materi pelajaran. LKS merupakan alat bantu untuk menyampaikan pesan kepada siswa yang digunakan oleh guru dalam proses pembelajaran. Melalui LKS ini akan memudahkan guru dalam menyampaikan materi pembelajaran dan mengefektifkan waktu, serta akan menimbulkan interaksi antara guru dengan siswa dalam proses pembelajaran (Senam, 2008). Lembar Kerja Siswa (LKS) adalah salah satu bentuk program yang berlandaskan atas tugas yang harus diselesaikan dan berfungsi sebagai alat untuk mengalihkan pengetahuan dan keterampilan sehingga mampu mempercepat tumbuhnya minat siswa dalam mengikuti proses pembelajaran (Sriyono, 1992). LKS berfungsi untuk 1) mengaktifkan siswa dalam proses belajar mengajar. 2) membantu siswa dalam mengembangkan konsep. 3) melatih siswa untuk menemukan dan mengembangkan proses belajar mengajar. 4) membantu guru dalam menyusun pelajaran. 5) sebagai pedoman guru dan siswa dalam melaksanakan proses pembelajaran. 6) membantu siswa memperoleh catatan tentang materi yang dipelajari melalui kegiatan belajar. 7) membantu siswa untuk menambah informasi tentang konsep yang dipelajari melalui kegiatan belajar secara sistematis (Prianto dan Harnoko, 1997).

Daya tarik suatu mata pelajaran (pembelajaran) ditentukan oleh mata pelajaran dan kedua oleh cara mengajar guru. Kebanyakan guru dalam mengajar cenderung menghapal dan konvensional, serta peserta didik juga pasif dalam belajar (Sugiyono, 2009). Situasi belajar seperti tersebut juga ditemukan pada proses pembelajaran mata pelajaran kimia di MAN 2 Kota Padang. Pada proses pembelajaran siswa kurang berperan aktif sehingga berdampak jelek tehadap hasil proses pembelajaran baik pada ulangan harian, ujian tengah semester maupun ujian akhir semester. Sebagai gambaran terlihat pada hasil proses pembelajaran kimia lintas minat kelas X IS 2 MAN 2 Kota Padang Semester Ganjil Tahun Pembelajaran 2017/2018 khususnya pada nilai ulangan KD 3.1 dan 4.1 siswa yang tuntas hanya 20,28\% (11 dari 39 siswa) dan nilai rata-rata kelas 68,74 dengan nilai KKM kelas X IS 2 adalah 75. 
Guru harus berperan aktif menemukan solusi dengan memilih alternatif model yang dapat mengaktifkan siswa. Kolaborasi STAD dengan LKS dan peta konsep diduga kuat dapat memperkuat motivasi dan meningkatkan parsipasi aktif siswa dalam proses pembelajaran. Sehubungan dengan itu telah dilakukan penelitian yang bertujuan untuk mengetahui pendekatan model kooperatif tipe STAD disertai LKS dan peta konsep dalam meningkatkan motivasi dan prestasi pembelajaran kimia MAN 2 Kota Padang.

\section{METODE PENELITIAN}

Penelitian tindakan kelas dilakukan pada kelas X IS 2 MAN 2 Kota Padang dari bulan Juli 2017-September 2017. Subjek dalam penelitian adalah siswa kelas X IS 2 MAN 2 Kota Padang yang terdaftar pada semester ganjil tahun pembelajaran 2017/2018 dengan jumlah siswa sampel adalah 39 siswa. Penelitian dilakukan dengan tindakan kelas dengan cara penerapan model pembelajaran Student Teams Achievement Division (STAD) yang disertai LKS dan Peta Konsep. Materi yang dipilih adalah ikatan kimia pada mata pelajaran kimia lintas minat kelas X IS 2 MAN 2 Kota Padang.

Penelitian dirancang atas dua siklus dan setiap siklus terdiri dari empat tahap. Penelitian siklus I terdiri dari empat tahap yaitu perencanaan, pelaksanaan tindakan, evaluasi dan tindakan. Pada tahap perencanaan terdiri dari langkahlangkah rencana pelaksanaan pembelajaran dikelas dengan menggunakan model pembelajaran Student Teams Achievement Division dengan langkah-langkah sebagai berikut: a. Menentukan pokok bahasan,

b. Menyusun Silabus, c. Menyiapkan Rencana Pelaksanaan Pembelajaran (RPP), d. Menyusun bahan ajar, e. Menyusun lembaran kerja siswa, f. Menyusun Lembar observasi aktifitas siswa dan g. Membuat soal tes untuk menilai hasil belajar siswa.

Tahap pelaksanaan tindakan siklus I terdiri dari; a). Pendahuluan yaitu memberikan motivasi pada siswa dan menginformasikan pada siswa mengenai konsep-konsep yang akan dipelajari, serta menjelaskan materi pelajaran. b). Kegiatan inti yaitu pelaksanaan pembelajaran dengan menggunakan STAD (Slavin, 2009). Langkah-langkah dalam penerapan model STAD adalah sebagai berikut: a) guru membagi anggota kelas menjadi delapan kelompok, setiap kelompok terdiri dari 4-5 orang siswa dengan kemampuan yang berbeda. Materi ikatan kimia yang akan didiskusikan dalam kelompok sesuai dengan indikator, ditulis pada kertas kecil masing-masing satu indikator. Tiap kelompok mencabut undian dan mendiskusikan materi dalam kelompok sesuai dengan indikator yang tertulis. b) Masing-masing kelompok mengkolaborasi materi pembelajaran yang diberikan dengan kehidupan mereka sehari-hari. Serta menyusun rencana penyampaian materi dan menghubungkan materi sesuai dengan yang ditemui dalam kehidupan sehari-hari kepada temannya. c) Hasil diskusi masing-masing kelompok yang akan disampaikan ditulis pada kertas karton. d) Setelah siswa berdiskusi dilakukan presentasi masing-masing kelompok sesuai dengan urutan nomor undian. e) Semua anggota kelompok tampil kedepan, dan yang tampil menyajikan materi dipilih berdasarkan suara terbanyak. Materi yang dijelaskan sesuai yang ditulis pada kertas karton dan ditempelkan pada papan tulis. Sebelum 
materi disajikan, moderator kelompok menginstruksikan agar masing-masing kelompok mempersiapkan pertanyaan. Semua anggota kelompok punya peran aktif untuk menjawab pertanyaan dari masing-masing kelompok. Dan masingmasing kelompok aktif bertanya sehingga siswa dalam mendiskusikan materi pembelajaran aktif semua. f) Guru memberikan kuis untuk siswa secara individual. g) Guru memberikan penghargaan pada kelompok melalui skor penghargaan berdasarkan perolehan nilai peningkatan hasil belajar individual dari skor dasar ke skor kuis berikutnya. h) Penutup yaitu memberikan kesimpulan dan evaluasi.

Tahap Pengamatan yaitu guru mengamati kegiatan pembelajaran siswa dengan menerapkan model Student Teams Achievement Division terhadap materi yang diperoleh siswa, mempresentasikan materi masing-masing kelompok kedepan kelas dan mengerjakan ujian secara individual melalui tes. Tahap refleksi yaitu guru merefleksikan kembali tentang pembelajaran yang telah dilakukan dengan menerapkan model Student Teams Achievement Division guru melihat masalah-masalah yang terjadi dan mengevaluasi hasil belajar siswa.

Proses pada siklus II tahap persiapan pembelajaran menggunakan LKS, masing-masing kelompok berdiskusi mengisi LKS dan menyimpulkan materi dalam bentuk peta konsep. Hasil diskusi, siswa dapat mengaplikasikan ikatan kimia yang terdiri dari ikatan ion, ikatan kovalen, ikatan logam, dan dan ikatan hidrogen kedalam peta konsep. Yang ditulis pada kertas karton manila dan akan dipresentasikan masing-masing kelompok kedepan kelas dijelaskan dalam bentuk peta konsep. Perbedaan pada siklus II merupakan perbaikan dari siklus I. Pada siklus II pembelajaran ikatan kimia dengan metode Student Teams Achievement Division disertai dengan LKS dan peta konsep. Masing-masing kelompok dapat melakukan perbaikan nilai dilihat hasil evaluasi dan refleksi dari siklus I. Lalu pada akhir siklus II dilakukan evaluasi untuk melihat hasil yang diharapkan pada siklus II. Dari hasil tersebut dianalisis dan direfleksikan kembali.

\subsection{Analis data}

Ada dua katagori ketuntasan belajar, yaitu secara perorangan dan secara klasikal. Ketuntasan belajar perorangan tercapai bila siswa memperoleh nilai $\geq 75$ dan ketuntasan belajar klasikal tercapai jika kelas tersebut $85 \%$ siswa yang memperoleh nilai $\geq 75$. Untuk mencari nilai rata-rata digunakan rumus :

$$
\overline{\mathrm{x}}=\frac{\Sigma \mathrm{x}}{\mathrm{N}}
$$

dengan: $\overline{\mathrm{x}}=$ nilai rata-rata, $\Sigma \mathrm{x}=$ jumlah semua nilai siswa, $\mathrm{N}=$ jumlah seluruh siswa.

Pencapaian hasil dikonversikan berdasarkan pencapaian hasil belajar seperti Tabel 1 (Sudijono, 2009). Bila siswa mendapat nilai besar dari KKM (75) maka predikatnya baik sedangkan prediket gagal yaitu jika siswa mendapat nilai kecil dari KKM. Keaktifan siswa dalam proses belajar mengajar diamati berdasarkan deskriptor yang tampak sedangkan untuk persentase aktivitas pada masing-masing deskriptor digunakan persamaan 1. Rentang prediket (\%) keaktifan siswa mengacu pada Sudijono (2009) dengan katagori keaktifan siswa seperti pada Tabel 2.

$$
\text { Persentase aktivitas }(\%)=\frac{\text { skor keaktifan }}{\text { skor total keaktifan }} \times 100 \% \ldots \ldots \ldots . .(\text { persamaan } 1)
$$


Ket: $\quad$ skor keaktifan $=$ Jumlah siswa yang melakukan aktifitas pada masing masing deskriptor. Skor total keaktifan = Jumlah siswa yang melakukan aktifitas pada semua deskriptor.

Tabel 1. Pencapaian hasil belajar kognitif siswa

\begin{tabular}{ccc}
\hline Nilai Angka & Nilai Huruf & Predikat \\
\hline$>\mathbf{8 5}$ & A & Baik sekali \\
\hline $\mathbf{7 5 - 8 4}$ & B & Baik \\
\hline $\mathbf{6 5 - 7 4}$ & C & Cukup \\
\hline $\mathbf{5 5 - 6 4}$ & D & Kurang \\
\hline$<54$ & E & Gagal \\
\hline
\end{tabular}

Tabel 2. Rentang predikat keaktifan siswa

\begin{tabular}{cc}
\hline Keaktifan siswa & Predikat \\
\hline $\mathbf{8 5 - 1 0 0}$ & Sangat Baik \\
\hline $\mathbf{7 0 - 8 4}$ & Baik \\
\hline $\mathbf{5 5 - 6 9}$ & Cukup \\
\hline $\mathbf{0 - 5 4}$ & Kurang \\
\hline
\end{tabular}

\section{HASIL DAN PEMBAHASAN}

1. Hasil

Hasil penelitian tindakan kelas (PTK) tentang penggunaan pendekatan model kooperatif tipe Student Teams Achievement Division (STAD) disertai dengan LKS dan peta konsep dalam meningkatkan motivasi dan prestasi pembelajaran kimia MAN 2 Kota Padang meliputi ranah kognitif, afektif dan psikomotor. Masing-masing ranah diuraikan sebagai berikut:

a. Ranah kognitif

Pendekatan model kooperatif tipe STAD disertai dengan LKS dan peta konsep dapat meningkatkan hasil pembelajaran kimia lintas minat pada ranah kognitif siswa kelas X IS 2 MAN 2 Kota Padang (Gambar 1). Terjadi peningkatan nilai rata-rata kelas sebesar 16,84 dari pra penelitian (To) ke siklus 1 (T1), dan sebesar 12,21 dari siklus 1 (T1) ke siklus 2 (T2) (Gamabar 1A). Selain itu, juga terjadi peningkatan ketuntasan siswa secara kelasikal sebesar 17,95\% dari pra penelitian (To) ke siklus 1 (T1), dan sebesar 30,77\% dari siklus 1 (T1) ke siklus 2 (T2) (Gambar 1B). 


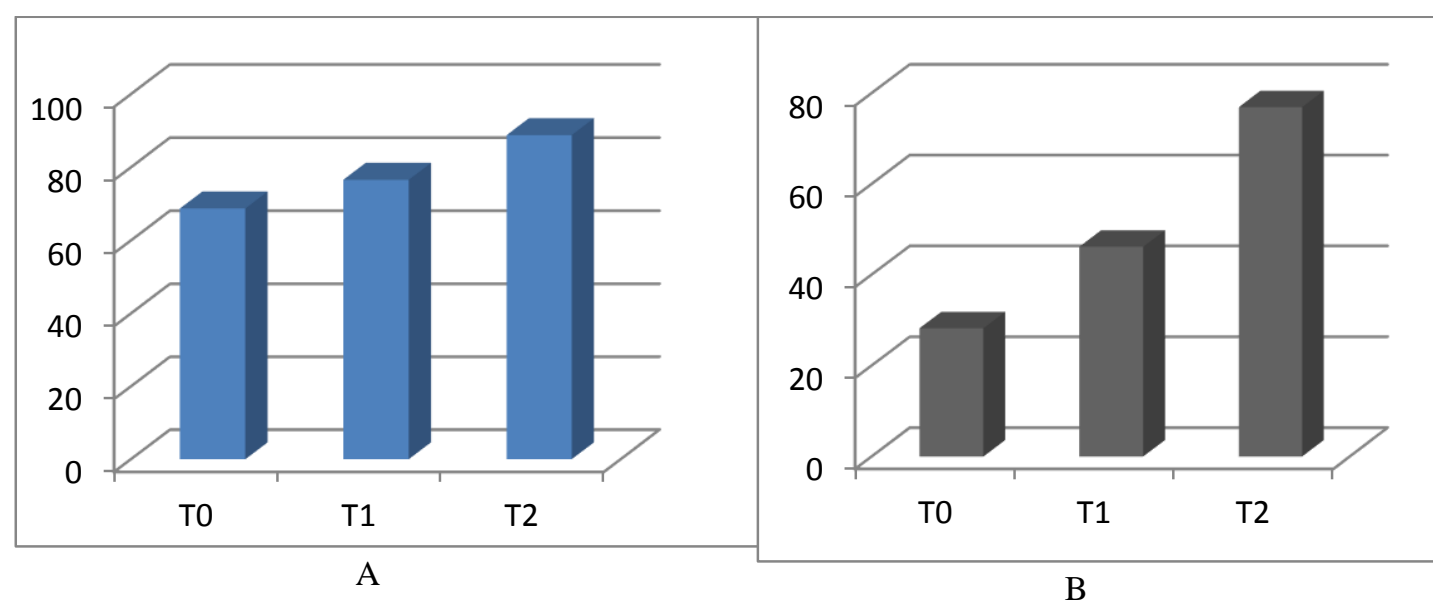

Ket:

A. Nilai rata-rata kelas dari dua siklus penelitian.

B. $\quad \mathrm{B}=$ Persentase $(\%)$ jumlah siswa yang memiliki nilai ketuntasan sesuai dengan KKM yang telah ditetapkan dari dua siklus penelitian. Pada ranah kognitif siswa kelas X IS 2 MAN 2 Kota Padang.

C. $\mathrm{T} 0=$ kondisi siswa pada pra penelitian,

D. T1= evaluasi pada akhir siklus 1

E. $\mathrm{T} 2=$ evaluasi pada akhir siklus 2 .

Gambar 1. Hasil penilaian ranah kognitif siswa selama kegiatan pembelajaran kimia lintas minat dengan menggunakan pendekatan model kooperatif tipe student teams achievement division (STAD) disertai dengan LKS dan peta konsep pada siswa kelas X IS 2 MAN 2 Kota Padang.

b. Aktivitas

Pendekatan model kooperatif tipe Student Teams Achievement Division disertai dengan LKS dan peta konsep dapat meningkatkan sikap positif siswa kelas X IS 2 MAN 2 Kota Padang (Gambar 2). Terjadi peningkatan sikap positif $11-23 \%$ dari pra-penelitian ke siklus 1 dan sebesar 6-43\% dari siklus 1 ke siklus 2. Pada penelitian siklus 1 terjadi peningkatan terbesar pada aktifitas tidak mencontek dalam ujian (26\%), dan terkecil pada aktifitas masuk kelas tepat waktu $(11 \%)$ dan bertanya materi yang belum dipahami (11\%). Pada siklus 2 peningkatan terbesar pada aktifitas bertanya materi yang belum dipahami (43\%) dan menjawab pertanyaan (43\%) sedangkan yang terkecil pada aktifitas masuk kelas tepat waktu $(0 \%)$.

Penerapan pendekatan model kooperatif tipe STAD disertai dengan LKS dan peta konsep dapat menurunkan sikap negatif siswa kelas X IS 2 MAN 2 Kota Padang (Gambar 3). Terjadi penurunan aktifitas negatif 17-3\% dari pra-penelitian ke siklus 1 dan sebesar 43-0\% dari siklus 1 ke siklus 2. Pada penelitian siklus 1 terjadi penurunan terbesar pada aktifitas terlambat mengumpulkan tugas (23\%) dan terkecil pada aktifitas pasif mengantuk dalam belajar (3\%). Pada siklus 2 penurunan terbesar pada aktifitas pasif selama kegiatan PBM (43\%) dan terkecil pada aktifitas sering keluar dalam belajar $(0 \%)$. 


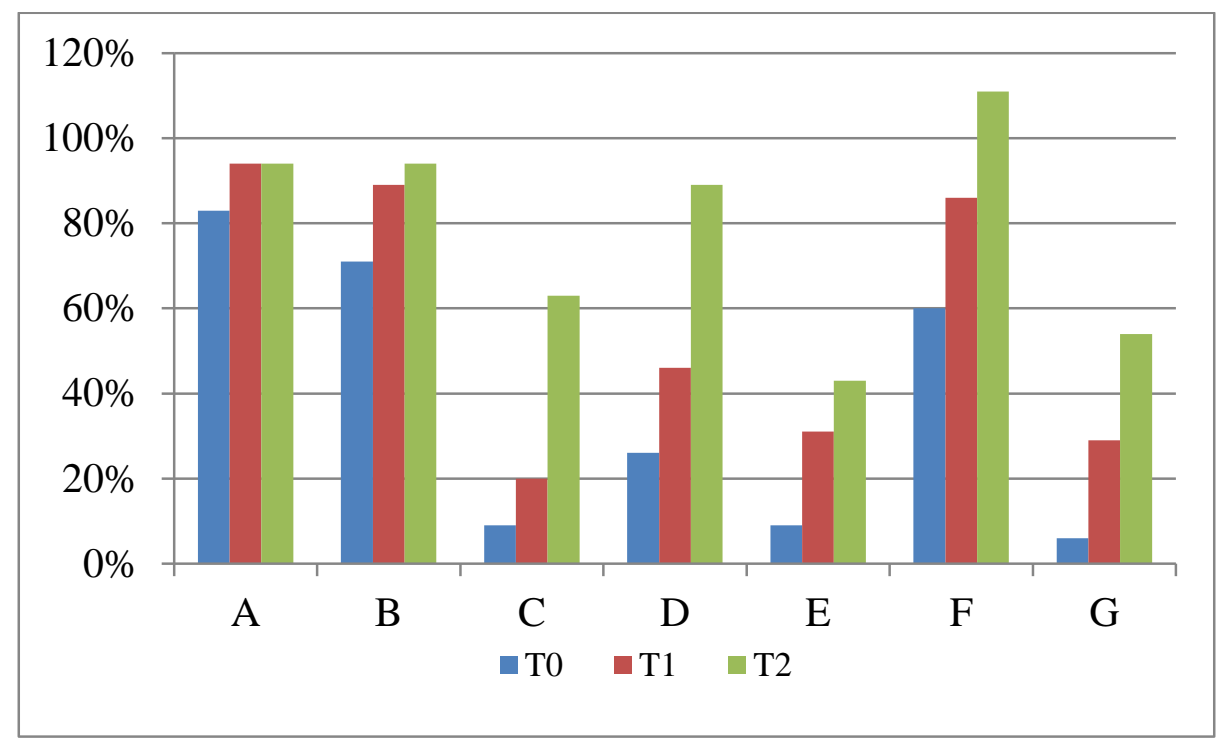

Ket:

$\mathrm{A}=$ Masuk kelas tepat waktu,

$\mathrm{B}=$ Mengumpulkan tugas tepat waktu,

$\mathrm{C}=$ Bertanya materi yang belum dipahami,

$\mathrm{D}=$ Menjawab pertanyaan,

$\mathrm{E}=$ Memberikan komentar dalam diskusi pertanyaan,

$\mathrm{F}=$ Tidak mencontek dalam ujian,

$\mathrm{G}=$ Menjelaskan dan memimpin diskusi.

$\mathrm{T} 0=$ aktifitas siswa pada prapenelitian,

$\mathrm{T} 1=$ aktifitas siswa pada siklus 1

T2= aktifitas siswa pada siklus 2 .

Gambar 2. Aktifitas sikap positif siswa selama kegiatan pembelajaran kimia lintas minat dengan menggunakan pendekatan model kooperatif tipe student teams achievement division (STAD) disertai dengan LKS dan peta konsep pada siswa kelas X IS 2 MAN 2 Kota Padang.

\subsection{Pembahasan}

Penerapan model kooperatif tipe STAD disertai dengan LKS dan peta konsep pada materi ikatan kimia dapat meningkatkan hasil pembelajaran kimia lintas minat pada ranah kognitif siswa kelas X IS 2 MAN 2 Kota Padang (Gambar 1). Hasil yang sama juga telah dilaporkan oleh Utomo (2012) terhadap hasil belajar geografi di SMA Negeri 1 Purwosari dan Wati (2011) pada siswa kelas XI IPS di SMA Negeri 9 Malang bahwa pembelajaran metode kooperatif dengan menggunakan model STAD berpengaruh signifikan terhadap hasil belajar siswa.

Penerapan model kooperatif tipe STAD disertai dengan LKS dan peta konsep pada materi ikatan kimia dapat meningkatkan hasil pembelajaran kimia lintas minat pada ranah kognitif siswa kelas X IS 2 MAN 2 Kota Padang (Gambar 1). Meningkatnya hasil pembelajaran kognitif siswa salah satunya disebabkan pendekatan model kooperatif tipe STAD disertai dengan LKS dan peta konsep pada ikatan kimia memberi kesempatan bagi siswa untuk menerapkan pengetahuan yang dimilikinya dalam menyelesaikan berbagai persoalan yang dihadapinya. Mengacu pada Sugiyanto (2007) siswa mempunyai kesempatan 
untuk mendapatkan pengetahuan langsung dalam menerapkan ide-ide, memberi kesempatan bagi siswa untuk menemukan dan menerapkan ide-ide mereka sendiri.

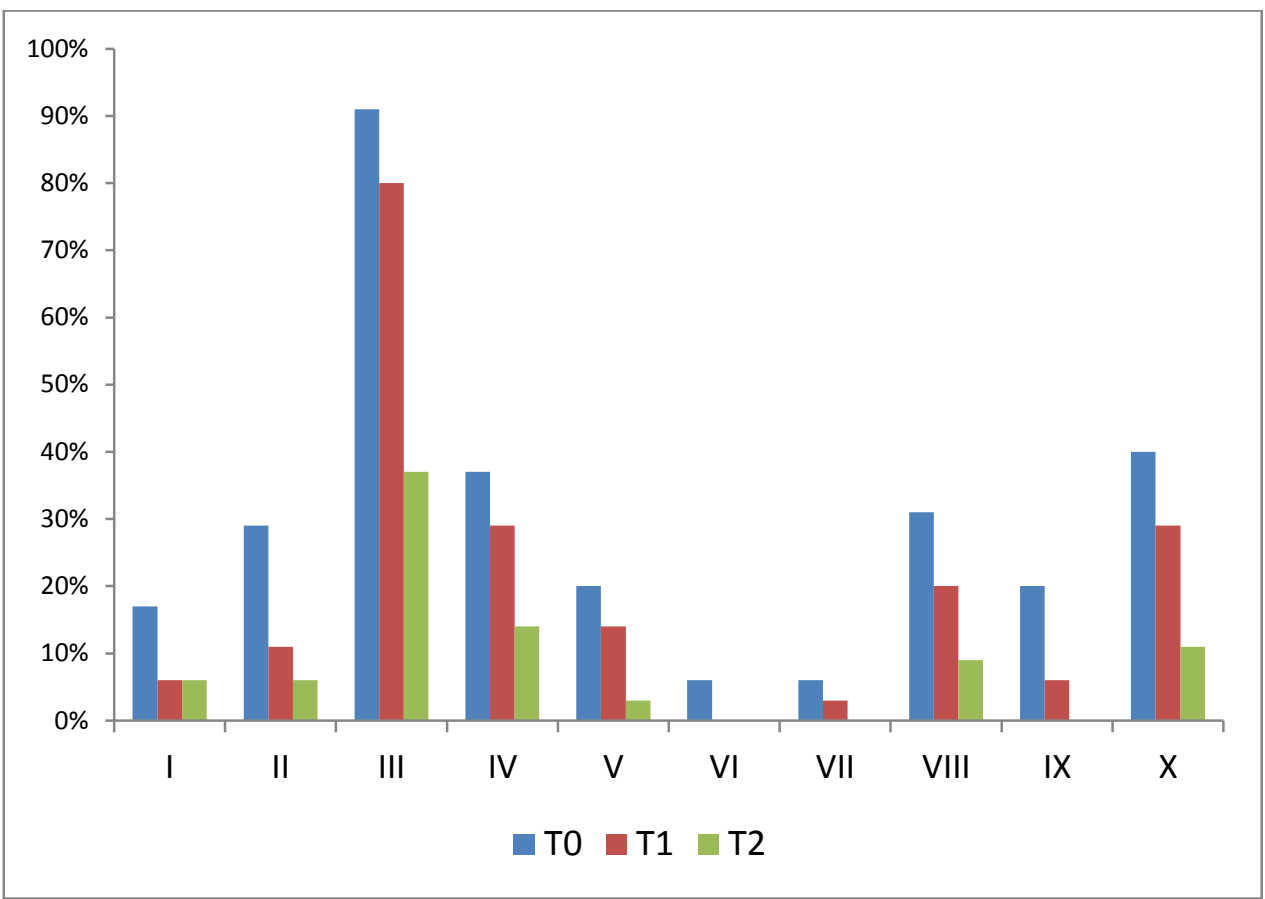

Ket:

$\mathrm{I}=$ Masuk kelas terlambat,

$\mathrm{II}=$ Terlambat mengumpulkan tugas,

III= Pasif selama kegiatan PBM,

$\mathrm{IV}=$ Mengganggu teman dalam belajar,

$\mathrm{V}=$ Mengerjakan pekerjaan lain,

$\mathrm{VI}=$ Sering keluar dalam belajar,

VII= Mengantuk dalam belajar,

VIII= Mengobrol dalam belajar,

$\mathrm{IX}=$ Makan dan minum dalam belajar,

$\mathrm{X}=$ Mencontek dalam ujian.

$\mathrm{T} 0=$ aktifitas siswa pada prapenelitian,

$\mathrm{T} 1=$ aktifitas pada siklus 1 dan

$\mathrm{T} 2=$ aktifitas siswa pada siklus 2 .

Gambar 3. Aktifitas negatif siswa selama kegiatan pembelajaran kimia lintas minat dengan menggunakan pendekatan model kooperatif tipe student teams achievement division (STAD) disertai dengan LKS dan peta konsep pada siswa kelas X MIA 6 MAN 2 Kota Padang.

Selain kemampuan menerapkan pengetahuan, pendekatan model kooperatif tipe STAD disertai dengan LKS dan peta konsep pada materi ikatan kimia memberi kesempatan bagi siswa untuk berkreatif dan produktif dalam konteks nyata. Mengacu pada Musfiqon (2012) bahwa siswa menemukan fakta, konsep, atau prinsip bagi diri mereka sendiri. Peserta didik memperoleh ilmu pengetahuan dan keterampilan yang dapat diaplikasikan dan ditransfer dari satu konteks permasalahan yang satu ke permasalahan lainnya. Kekompakan dan kerja sama yang solid antar kelompok menentukan keberhasilan pembelajaran 
karena satu sama lain akan memberikan informasi yang telah di dapat dari kelompok lain.

Pendekatan model kooperatif tipe STAD disertai dengan LKS dan peta konsep dapat meningkatkan rata-rata kelas sebesar 12,21 dari siklus 1 ke siklus 2 (Gambar 1). Mengacu pada Soeharto (2003) bahwa pembelajaran yang dirancang adalah sesuatu yang memang dari semula dirancang untuk keperluan belajar, sedangkan pembelajaran yang tinggal pakai atau jadi adalah sesuatu yang pada mulanya tidak dimaksudkan untuk kepentingan belajar, tetapi kemudian dimanfaatkan untuk kepentingan belajar.

LKS merupakan sebuah media pembelajaran yang membawa pesan-pesan yang memuat tujuan instruksional pengajaran sehingga dapat meningkatkan nilai rata-rata kelas siswa kelas X IS 2 MAN 2 Kota Padang. Mengacu pada Sriyono (1992), bahwa LKS merupakan suatu bentuk program yang berlandaskan atas tugas yang harus diselesaikan dan berfungsi sebagai alat untuk mengalihkan pengetahuan dan keterampilan sehingga mampu mempercepat tumbuhnya minat siswa dalam mengikuti proses pembelajaran. LKS membawa pesan-pesan berupa ide, gagasan, dan penemuan-penemuan, media memiliki andil yang cukup besar dalam mengajar dan mendidik siawa untuk menjadi manusia yang seutuhnya (Arsyad, 2013). Pesan-pesan yang tersalurkan dari media pembelajaran LKS ini dikonsep dan disusun sedemikian rupa dalam bentuk peta konsep sehingga pembelajaran yang berlangsung lebih terarah dan terstruktur.

Selain sebagai media pembelajaran, LKS juga merupakan sarana penyaluran ide dari siswa yang dapat diaplikasikan dalam kehidupannya. Mengacu pada Munadi (2008), segala sesuatu yang dapat menyalurkan pesan dari sumber terencana sehingga tercipta lingkungan belajar yang kondusif dimana penerimanya dapat melakukan proses belajar secara efisien dan efektif. Daryanto (2010), sebagai suatu komponen integral dari sistem pembelajaran media berada di posisi yang sentral dalam proses kegiatan belajar mengajar. Media menjadi sarana penyaluran ide dari sumber yang dikemas dalam kode-kode yang tersampaikan secara tersurat dan tersirat sehingga pesan tersebut bisa tersalurkan dan ditafsirkan dengan baik oleh peserta didik Siswa diberi kesempatan untuk menyusun sendiri konsep-konsep dalam struktur kognitifnya, selanjutnya dapat diaplikasikan dalam kehidupannya.

Penerapan pendekatan model kooperatif tipe STAD disertai dengan LKS dan peta konsep pada materi ikatan kimia dapat meningkatkan sikap siswa yang bersifat positif sebesar 6-43\% (Gambar 2). Terjadinya peningkatan aktitas yang bersifat positif pada siswa diduga kolaborasi model kooperatif tipe STAD disertai dengan LKS dan peta konsep menuntut adanya tanggungjawab individual siswa. Hal ini karena model pembelajaran STAD termasuk dalam model pembelajaran kooperatif yang berperan dalam meningkatkan kerjasama dan keaktifan siswa. Mengacu pada Nurhadi (2004) bahwa pembelajaran kooperatif adalah pembelajaran yang secara sadar dan sengaja menciptakan interaksi yang saling mengasihi antar sesama teman sehingga sumber belajar tidak hanya guru dan buku ajar tetapi juga sesama siswa. Berbeda dengan pembelajaran konvensional yang berpusat pada guru (teacher centered) yang tidak melibatkan siswa secara aktif dalam kegiatan pembelajaran sehingga siswa tidak mempunyai kesempatan untuk 
menggali kemampuan dan potensi yang dimilikimya. Kondisi demikian yang menyebabkan aktivitas siswa selama mengikuti kegiatan pembelajaran juga berbeda.

Peningkatan aktifitas sikap positif yang terbanyak pada siklus 1 terjadi pada dua aktifitas yaitu bertanya materi pelajaran yang kurang dipahami dan menjawab pertanyaan sebesar $43 \%$ (Gambar 2). Tingginya persentase peningkatan pada kedua aktifitas tersebut disebabkan semua anggota kelompok diberi tanggungjawab selama kegiatan pembelajaran. Mengacu pada Soewarso (1998) salah satu kelebihan model STAD adalah menjadikan siswa mampu belajar berdebat, belajar mendengarkan pendapat orang lain, dan mencatat hal-hal yang bermanfaat untuk kepentingan bersama.

Peningkatan aktifitas sikap positif yang paling sedikit terjadi pada aktifitas pada aktifitas masuk kelas tepat waktu yaitu 43-0\% (Gambar 2). Kecilnya persentase siswa yang terlambat masuk pada awal pembelajaran disebabkan jadwal mata pelajaran kimia terletak diantara mata pelajaran lain. Mata pelajaran yang terletak pada dua mata pelajaran memperkecil peluang siswa untuk terlambat masuk pada jadwal jam pembelajaran.

Penerapan model kooperatif tipe STAD disertai dengan LKS dan peta konsep pada materi ikatan kimia dapat menurunkan sikap siswa yang bersifat negatif sebesar 6-43\% (Gambar 3). Besarnya persentase penurunan aktifitas pasif selama penerapan model kooperatif tipe STAD disertai dengan LKS dan peta konsep diduga model STAD sebagai model pembelajaran yang menuntut kerjasama akan dapat meningkatan keaktifan siswa selama proses pembelajaran di kelas. Dengan adanya kerjasama dalam setiap kelompok akan membantu siswa dalam memahami materi pelajaran karena siswa dapat bertukar pikiran, berbagi pendapat, saling membantu, dan memberi motivasi. Mengacu pada Soewarso (1998) bahwa model STAD adalah dapat a) membantu siswa mempelajari isi materi pelajaran yang sedang dibahas, b) menghasilkan pencapaian belajar siswa yang tinggi serta menambah harga diri siswa dan memperbaiki hubungan dengan teman sebaya, c) hadiah atau penghargaan yang diberikan akan memberikan dorongan bagi siswa untuk mencapai hasil yang lebih tinggi dan d) pembentukan kelompok-kelompok kecil memudahkan guru untuk memonitor siswa dalam belajar bekerja sama.

Aktifitas negatif pada siswa kelas X IS 2 MAN 2 Kota yang mengalami penurunan terbesar selama penelitian adalah pasif selama kegiatan PBM yaitu $43 \%$ (Gambar 3). Besarnya persentase penurunan aktifitas pasif selama kegiatan PBM karena setiap siswa dapat saling memotivasi di dalam kelompok. Mengacu pada Slavin (2008) bahwa gagasan utama dari STAD adalah untuk memotivasi siswa supaya dapat saling mendukung dan membantu siswa lain dalam menguasai kemampuan yang diajarkan oleh guru. Latuheru (1988), hal tersebut dapat menunjang interaksi dalam proses pembelajaran baik interaksi antar siswa ataupun guru karena dalam kegiatan pembelajaran perlu adanya komunikasi antara guru dan siswa. Komunikasi yang terjadi pada kegiatan pembelajaran merupakan komunikasi interaktif edukatif. Hal ini berarti komunikasi yang dilakukan antara guru dan siswa, ataupun siswa dengan siswa berupa materi pelajaran yang tepat guna. 
Aktifitas negatif yang mengalami penurunan paling sedikit selama penelitian pada siswa kelas X IS 2 MAN 2 Kota adalah aktifitas sering keluar dalam belajar yaitu sebesar 0\% (Gambar 3). Kecilnya persentase penurunan pada aktifitas tersebut dikarenakan penerapan model kooperatif tipe STAD disertai LKS dan peta konsep dapat mengantisipasi aktifitas tersebut. Mengacu pada Slavin (2008) bahwa kelebihan lain dari model STAD adalah adanya penghargaan bagi tim terbaik. Ada lima komponen utama di dalam STAD yaitu presentasi kelas, tim, kuis, skor kemajuan individual dan rekognisi tim. Dengan adanya penghargaan, akan menjadi motivator bagi siswa untuk menjadikan kelompoknya menjadi yang terbaik sehingga membuat siswa lebih termotivasi untuk belajar lebih giat. Dengan demikiam, tidak memungkin bagi siswa untuk keluar meninggalkan kelompok diskusi karena akan berpengaruh terhadap pencapaian hasil belajar siswa secara individu.

\section{KESIMPULAN}

Pendekatan model kooperatif tipe Student Teams Achievement Division (STAD) disertai dengan LKS dan peta konsep dapat meningkat hasil pembelajaran kognitif, aktifitas positif dan menurunkan aktifitas negatif dalam pembelajaran kimia lintas minat pada siswa kelas X IS 2 MAN 2 Kota Padang.

\section{DAFTAR RUJUKAN}

Arikunto, S. 2006. Prosedur Penelitian Suatu Pendekatan Praktek. Rineka Cipta. Jakarta.

Arindawati. 2004. Model Pembelajaran Student Team Achievement Division. Http://www.Scrbd.com. Diakses 15 Desember 2017.

Hafid Hasarudin. 2011. Skripsi Menggunakan Model Pembelajaran Kooperatif Tipe STAD.

Makassar: Universitas Negeri Makassa.

Azhar, A. 2013. Media Pembelajaran. Rajagrafindo Persada. Jakarta.

Daryanto. 2010. Media Pembelajaran. Gava Media. Yogyakarta.

Latuheru, J. D. 1988. Media Pembelajaran Dalam Proses Belajar Mengajar Masa Kini.

Departemen Pendidikan dan Kebudayaan. Jakarta.

Unadhi, Y. 2008. Media Pembelajaran Sebuah Pendekatan Baru. Jakarta.

Musfiqon. 2012. Pengembangan Media dan Sumber Media Pembelajaran. Prestasi

Pustakaraya. Jakarta. 
Nurhadi. 2004. Pembelajaran Kontekstual dan Penerapanya dalam KBK. Universitas Negeri Malang Press. Malang.

Putro, B. R. 2011. Penerapan Model Pembelajaran Kooperatif STAD untuk Meningkatkan Keaktifan Belajar Geografi Siswa Kelas X9 SMAN 1 Purwosari Kompetensi Dasar Mendeskripsikan Tata Surya dan Jagad Raya. Skripsi. Universitas Negeri Malang. Malang.

Prianto dan Harnoko. 1997. Perangkat Pembelajaran. Depdikbud. Jakarta.

Atmaja, S. U. 2008. Teori dan Praktek Senam. Bandung: FPOK-UPI.

Slavin, R. E. 2008. Cooperative Learning Teori, Riset dan Praktik. Bandung. Nusa Media.

Soeharto, K. 2003. Teknologi Pembelajaran. Surabaya Intellectual Club. Surabaya.

Soewarso. 1998. Menggunakan Strategi komparatif Learning di dalam Pendidikan Ilmu Sosial. Edukasi 01:16-25.

Sriyono. 1992. Teknik Belajar Mengajar dalam CBSA. Rineka Cipata. Jakarta.

Sudijono, A. 2009. Pengantar Evaluasi Pendidikan. Rajawali Pers. Jakarta.

Sugiyanto. 2007. Penelitian Administrasi. Alfabeta. Bandung.

Sugiyono. 2009. Metode Penelitian Kuantitatif, Kualitatif dan R\&D. Alfabeta. Bandung.

Utomo, W. A. 2012. Pengaruh Model Pembelajaran Student Team Achievement Division (STAD) Terhadap Hasil Belajar Geografi Di SMA Negeri 1 Purwosari. Skripsi. Universitas Negeri Malang. Malang.

Wati, A. E. 2011. Pengaruh Metode Pembelajaran Kooperatif Tipe STAD (Student Teams Achievement Divisions) Terhadap Hasil Belajar Siswa Mata Pelajaran Akuntansi Kelas XI IPS di SMA Negeri 9 Malang. Skripsi. Universitas Negeri Malang. Malang. 